Nordisk Tidsskrift for Kriminalvidenskab 2010

\title{
BANDEKRIMINALITET OG FOREBYGGING
}

Forsker 1, DR. PoLIT. INGER-Lise LIEN

This paper discusses gang prevention within the Scandinavian context. The paper argues for a holistic approach based on a thorough analysis of the causes of crime and the processes of gang formation so that these can be targeted on a micro, meso and macro level. Migration seems to be one of the macro-level conditions that proliferates and seeps down to the lower levels. There is a need for measures directed towards education at early ages. The psychological pain that comes from life in the gang, such as that manifested in traumatic stress disorders, must be communicated to the young. Family programs are essential in order to strengthen the family and social control. It is also important to prevent the processes of withdrawal that often take place in areas where gang problems are most serious. Police work should be guided by a deep understanding, sharp analysis and thorough knowledge of the community, and of gang members'activities and lives, in order to provide relevant solutions in the form of arbitration and tension reduction, as well as deterrence. Nervousness among the police may trigger further tensions, such that the process of gang formation escalates. ${ }^{*}$

\section{Innledning}

Forebygging og problemløsning i forhold til gjeng eller bande problematikk krever først at en anerkjenner problemet, tar det alvorlig, analyserer det nøye, og så setter i gang tiltak basert på denne analysen. Dessverre har gjengproblematikken i flere land i Europa vært møtt med benektelser både når det gjelder fenomen og begrepsbruk (Klein et al 2001). Nå er vi kommet over den første fasen og er i gang med problemanalyse, kunnskapsinnhenting, og tiltak. I denne artikkelen vil vi først se nærmere på noen beskrivelser av årsaker, før vi diskuterer ulike måter å forebygge fenomenet på. Forfatteren av dette innlegget har stort sett beskjeftiget seg med innvandrergjenger. Diskusjonen vil derfor også fokusere på migrasjon som en makrofaktor som også sildrer ned på andre nivåer og indirekte kan innvirke på gjengdannelsen.

\section{Gjengprosessen}

En gjengprosess begynner gjerne med en fase hvor kriminaliteten først er usynlig for myndigheter og familie. Fasen kan beskrives som "gangs in process" (Feixa

\footnotetext{
Title in English: Gang Crime and Prevention. Original in Norwegian.
} 
et al. 2008). Det kan være vanskelig å forebygge og forhindre et individs tilknytning til gjenger i den fasen hvor gjengproblematikken er usynlig. Derfor er det viktig med en primær forebygging som retter seg bredt mot definerte målgrupper. Den andre fasen av prosessen oppstår når en har fått etablert en gategjeng ${ }^{1}$ - som ikke bare utøver plagsom atferd, men kriminell atferd av ulik slag. Noen har initiasjonsriter, og må gjøre seg fortjent til medlemskap. Enkelte har utviklet egen symbolikk og faktisk også egen dialekt/ språk. Gjenger utvikler seg gjerne i konkurranse og konflikt med andre gjenger (Trasher 1927). Det blir derfor viktig å dempe konflikter mellom grupper i et område, og forsøke å svekke gjengene ved å få medlemmer ut, for å forhindre at gruppene gjensidig styrker hverandre. Det er lettere tidlig i karrieren enn senere. Flere gjenger synes etter hvert å skli inn $\mathrm{i}$ narkotikaomsetningssystemet. Hvis de sklir inn på lavt nivå kan gjengen atomiseres, splittes opp og svekkes eller opphøre, selv om personene fortsetter å utøve krimininelle handlinger. På høyt nivå kan det virke som om gjengens samhold blir styrket. Det er på dette nivå vi kan omtale det som en organisert kriminell gruppe innenfor distribusjonssystemet. Her er det også vanskeligst å få medlemmene ut av den kriminelle løpebanen.

Eksempelvis begynte de pakistanske A- og B-gjengene i Oslo med småkriminalitet. Etter hvert begynte noen med utpressing. De investerte inn i narkotikaomsetningen på høyt nivå. Det sies at det tok B-gjengen ti år å komme på dette nivået. Den kollektive gjengfølelsen er opprettholdt, men det dannes nye allianser og det er konflikt og slåsskamper mellom gruppene som forsterker intern lojalitet. Kriminelle hemmeligheter, lojalitetsplikt og svart gjeld holder individene fast $\mathrm{i}$ systemet.

\section{Analyser}

Samfunnsforskerne har over år utviklet teorier på makro, meso og mikro nivå for å forstå utvikling av kriminalitet og gjengdannelse. Teoriene er relevante fremdeles, men tiltak baseres ofte ikke på grundige nok analyser. USA har drevet med tiltak mot gjengproblematikken siden tidlig 1900 tallet, men gjengproblematikken har økt, er blitt kronisk og har spredd seg til andre byer (Klein 1995). Flere av tiltakene har styrket gjengene, og ikke svekket dem. Vi må lære av amerikanernes feilskjær og bygge strategier som er forankret i forskningsbasert kunnskap om årsaker og virkninger, og følge opp tiltak med evalueringer. Vi finner gjerne at økonomiske og strukturelle forhold på et overordnet samfunnsnivå får forklaringskraft for omfanget av kriminalitet og gjengdannelse. Durkheim (1979) utviklet et skille mellom faktorer som forklarer et omfang ("the rate") og de som forklarer det enkelte tilfellet ("the incident"), dvs. han opererte med to nivåer av forklaringer av selvmord. Denne innsikten kan også overføres til gjengproblematikken. Det 
er andre faktorer som forklarer omfang, en de som forklarer det enkelte tilfellet. Store demografiske endringer, migrasjon og økonomisk fattigdom kan være med på å forklare omfang av gjenger i et område, mens fars konstante banking av sønnen, eller syk mor, kan være med på å forklare at en enkelt gutt søker til gjengen som erstatning for en dårlig fungerende familie. Vi trenger derfor tiltak rettet mot alle nivåene ut fra en komplementaritetshypotese, og teorier om synnergieffekter. Hvis vi skal forebygge et fenomen er det viktig å angripe problemet på samtlige nivåer, altså arbeide helhetlig med ulike tiltak tilpasset de enkelte nivå. Dette er også virkemidler som Hagedorn (2001) har foreslått innenfor den amerikanske konteksten.

\section{Mikro}

Maughan et al (1996) fant at barn med lesevansker hadde en økt risiko for å utøve antisosial atferd. Men om det skyldes IQ, dysleksi, eller en svak pedagogikk, kan være vanskelig å si. Svake skoleresultater og dropout vil derfor til en viss grad predikere sosiale avvik og kriminalitet. Det må derfor være viktig å rette tiltak mot barn på skolen slik at de greier skolehverdagen og gjennomfører. På det personlige plan viser det seg at høy impulsivitet og en negativ emosjonalitet (altså tendensen til å reagere med sinne, frykt og irritabilitet) kan assosieres med kriminalitet (Caspi et al. 1994), mens beskjedenhet og tilbaketrekking kan fungere som en beskyttende faktor (Farrington et al 1988). Konklusjonen i litteraturgjennomgangen til Rutter et al. (2004) viser at den mest robuste prediktor på mikro nivå er hyperaktivitet. I tillegg vil kognitive svakheter slik som svake verbale og rasjonelle evner skape sårbarhet for individet. Også impulsivitet og sensasjonssøkning, samt manglende selvkontroll, og kommunikative problemer og dårlig informasjonsbearbeidelse på det kognitive plan vil kunne lede til senere antisosial atferd, noe som også vil innebære sårbarhet til å rekrutteres til gjeng. Brede tiltak som barnehagetilbud, leksehjelp og pedagogisk psykologiske tilbud, vil dermed også kunne være gjengforebyggende.

\section{Meso}

Når det gjelder forhold i familien finner Farrington, Gundry og West (1975) at kriminalitet av andre familiemedlemmer, eksempelvis begått av far, har sammenheng med kriminalitet begått av sønner. Forhold internt i familien, eksempelvis foreldrenes negative holdning til egne barn, dårlig ekteskap, krangler internt, dårlig disiplin, kan øke risikoen for å komme i risikosonen, altså også føre til at barnet blir mer sårbart til å rekrutteres til gjenger dersom de finnes i området. Tiltak som forbedrer foreldres disiplineringsevne kan dermed resultere i nedgang av kriminalitet. Individer som ble foreldre i en alder under 21 år hadde større sjanser for å bli 
registrert for vold i nære relasjoner (Rutter et al. 2004:181), og også for skoledroppout (Maughan \& Lindelow 1997). Det betyr at det ligger et stort forebyggingspotensiale i å tilby foreldreopplæring og foreldrestøtte.

Hvis en oppdras i en familie med i det minste fire barn, så vil risikofaktorene gjerne øke (Rutter \& Giller 1983). Offord (1982) fant at øket risiko var assosiert i forhold til mange brødre og ikke i forhold til mange søstre. Forhold som gjør at foreldrene blir dårligere i sin oppdragergjerning kan være forskjellige, slik som skillsmisser, dødsfall, depresjoner, traumer og vold, fattigdom, men også store arbeidsbelastninger på foreldrene, og store familier.

I flere innvandrergjenger finner vi gjerne et mønster av familierekruttering, som vi ikke finner i de norske gjengene i samme grad (Lien 2005). Når et medlem av familien går inn så kan etter hvert hele familien oppslukes av gjengen. Flere slik grupper består av fire, fem eller seks brødre. Det betyr at det har skjedd en kjederekruttering internt i familien. Det kan være et stort problem for hjelpeapparatet å jobbe med familien, hvis mor og far støtter sønnenes kriminalitet. Det er også et problem å komme seg ut av gjengen når flere av brødrene er kommet innenfor

\section{Makro faktorer som sildrer ned til meso og mikro}

Migrasjon er en makrofaktor som siver ned på meso og mikro og som kan få konsekvenser for rekruttering til gjeng, og tap av foreldrekompetanse fordi foreldrene ikke greier å konvertere sin oppdragerkapital og kompetanse til det nye landet (Grønhaug 1979). En mor og far som er analfabet, mister evner til å kontrollere og styre ungdommen. En mor og far som er utrygge i det nye samfunnet, kan overreagere og gi ungene for mye bank. Kulturelle faktorer, blant annet æreskodeksen, er ideologisk, og vi kan plassere den på et makro nivå. Den kan spille inn og føre til sårbarhet ved at foreldrene er kulturelt instruert til å utøver sosial kontroll ovenfor jentene, men lar guttene gå fri. Ute på gatene kan det ha etablert seg gjenger. Disse kan virke som magneter på utrygge barn. Flere av mine informanter (Lien 2004) er blitt banket inn i gjengen av andre gjengmedlemmer fordi de har hengt ute i gatene.

Enkelte naboskap og områder kan utgjøre en risikofaktor på et makro nivå. Det er områder som har den laveste økonomiske status, høy barnedødelighet, familier som er avhengig av velferdsoverføringer osv. Det er ikke de økonomiske forhold i seg selv som nødvendigvis slår ut i mer kriminalitet, men en kombinasjon av faktorer. Dette er også områder hvor det gjerne er en stor etnisk variasjon og innvandring, store og hyppige demografiske endringer. Folk flytter ut og inn. Kriminaliteten kan ikke kobles til en bestemt etnisk gruppe, men til de forhold som eksisterer innenfor de områder som ulike etniske grupper flytter til. I en studie fra USA om naboskap, etnisk variasjon og tillit fant Putnam (2007) at etnisk variasjon korrelerte negativt med tillit. Mennesker som lever i homogene naboskap 
stoler mer på hverandre enn de som lever i etnisk forskjellige samfunn. Førtien naboskap over hele USA ble studert. Putnam og kolleger fant at forskjeller ledet til tilbaketrekning, mindre tillit til lokalt styre, lokale media, og mer tid ble brukt til å se fjernsyn.

"Diversity at least in the short run, seems to bring out the turtle in all of us.... Diverse communities tend to be larger, more mobile, less egalitarian, more crime-ridden and so on." (Putnam 2007:151).

Putnams primære mål var ikke å studere kriminalitet, men tillit innenfor flerkulturelle naboskap. Tilbaketrekningen, og den innadventhet, som han beskriver innenfor "multikulturelle områder" vil selvfølgelig få konsekvenser for sosial kontroll og således indirekte virke inn og skape grunnlag for kriminogene krefter og dannelsen av gjenger.

Innenfor æreskodeksen er maskulinitet en verdi som legger vekt på tøffhet og evnen til å forsvare seg (Black-Michaud 1975). En hypersensitivitet for fornærmelsen kan lede til at en lettere kan bli sint. En selvforståelse som blir instruert fra et overordnet analytisk paradigme, slik som en æreskodeks, kan få konsekvenser for omfanget av vold i et samfunn (Nisbet og Cohen op.cit). I tillegg kan det tenkes at et samfunn med svak statsdannelse kan føre til en æreskodeks som gir individer og klaner instruksjoner om å forsvare familien, og å være sensitive for fornærmelsen, noe som kan føre til mer vold, eller at en tar loven i egne hender. Det betyr også at der hvor statens institusjoner fungerer dårlig, eller har trukket seg ut, vil andre mekanismer kunne erstatte denne svakheten, og kanskje en æreskodeks blir nødvendiggjort på grunn av statlig eller kommunal tilbaketrekning. En svekkelse av statens institusjoner kan også gi muligheter for at gjenger oppstår i det vakum som institusjonene har etterlatt, og så tilraner gjengene seg makt over minoritetsbefolkningen ved å gi bøter og beskyttelse. Derfor vil det være viktig nettopp å styrke statens institusjoner i lokale områder der det ser ut til å være en utvikling av kriminalitet og gjengdannelse.

Tony Waters (1999) mener at gjengkriminalitet kan oppstå i andregenerasjonen fordi ungdommen utsettes for et stort assimileringspress. Dette er en migrasjons hypotese om kriminalitet som skyldes at foreldrenes oppdragerkompetanse svekkes på grunn av flere ulike forhold som har sin årsak i migrasjon. Det oppstår statusfrustrasjon blant en stor gruppe annengenerasjons ungdommer på grunn av et sterkt assimilasjonspress. Vi kan si det slik at 1. når foreldrene integreres for sakte inn i samfunnet så mister de foreldrekompetanse fordi de befinner seg i en fremmed kontekst. Det oppstår uheldige risikofaktorer som kan styrke asosialitet hos ungdommen. Vi kan også si det på denne måten 2. når ungdommen integreres 
for raskt inn i samfunnet i forhold til foreldrene, og må orientere seg mot jevnaldergruppen for å hente kunnskap om samfunnet, da styrkes asosialitet hos ungdommen. Hvis familiene i tillegg er svekket på grunn av sykdom, fravær av fedre, analfabetisme etc. kan det slå uheldig ut for ungdom som bebor områder hvor det kanskje allerede har etablert seg gjenger som de må forsvare seg mot, og forholde seg til. Van Gemert et al. (2008) viser at etnisitet ikke er en avgjørende faktor for kriminalitetsutvikling, men migrasjon utgjør en risiko for andregenerasjonens innvandrere fordi den kan føre til en forsterkning og en akkumulasjon av de risikofaktorene som gjelder for alle.

Sveinung Sandberg og Willy Pedersen (2006) har beskrevet den form for kapital som tiltrekker ungdom som selger narkotika i Oslo. De viser til faktorer som virker tiltrekkende som filmer og musikk som romantiserer gangsterlivet. De diskuterer også de kunnskaper som trengs for å operere effektivt innenfor dette feltet og beskriver det som spesielle kapitalformer som de omtaler som gatekapital. I tillegg er det former for anerkjennelse, spenning m.m som tiltrekker, status og beundring, selvstendighet, frigjøring, økonomi, fellesskap. I en artikkel om betydningen av kriminalitetshandlinger for å etablere en egen gjengmentalitet, har jeg vist (Lien 2005) hvordan ulike former for kriminalitet giør det mulig for den kriminelle å oppfatte seg som et godt menneske. De økonomiske ressurser som vedkommende tilegner seg på urettmessig vis kan transformeres til gaver og sjenerøsitet $\mathrm{i}$ forhold til venner og bekjente. Han blir dermed et godt menneske i andres øyne. Kriminaliteten gir en anledning til å bli oppfattet som ressurssterk hvis og når vedkommende greier å kompertmentalisere den kriminelle handling, altså forhindre at noen får greie på at ressursene er innhentet illegalt. Ressursene som oppnås gjør det altså mulig å oppnå positiv anerkjennelse som venn og hjelper. Altså kan en få rykte på seg for å være god, selv om en i en annen kontekst kan opptre brutalt. Dette viser nødvendigheten av å bryte kommunikasjonssperrene som ungdom i gjenger forsøker å etablere mellom de ulike sfærer de opptrer innenfor, slik at deres aktiviteter og problemer blir synliggjort for alle.

En trenger en modell for å forstå kriminalitet som innholder kompliserte samvirkende faktorer. Ifølge Klein (1995) finnes det ingen enkel årsak eller teori som kan forklare at ungdommer går inn i gjenger eller utøver kriminalitet. Han støtter en komplemenarititetshypotese, og sier følgende: "that these causes are so broad, so interconnected, that they are hard to isolate or treat separately. On the individual level they include a need for identity and status along with some deficits in some interpersonal relations. At the aggregate level they include poverty, inadequate educational processes, population shifts, and ethnic segregation".

Dette betyr at en er nødt til å arbeide bredt med tiltak på flere nivåer for å motvirke og forebygge gjengdannelse. 


\section{Hvordan kan en arbeide?}

Vi må tørre å stille vanskelige spørsmål. Hvordan kan en styrke statens institusjoner i de områder hvor gjengene etablerer seg? Hvordan kan en styre migrasjonen og integreringen slik at en forhindrer at det oppstår gjenger og kriminalitet, og minoriteten blir offer? Hvordan forhindre at næringsliv og velferdsinstitusjoner trekker seg ut av områder der gjengene holder til? Hvordan forhindre ghettodannelse? Hvordan forhindre at staten mister kontroll av områder slik som syns å ha skjedd enkelte steder i Frankrike? I en artikkel i le Figaro (1 februar 2002) uttaler kriminologen Lucienne Bui Trong at antall ZUS (zones urbaines sensibles), områder hvor myndighetene har hatt problemer med å kontrollere, hadde øket fra 106 i 1991 til 818 i 1999.

På et utendørs seminar i Gamle Oslo i 2009 hvor politikere fra flere partier deltok for å diskutere den økte vold og kriminalitet med oppvekst av kriminelle gjenger som har skjedd i Oslo, klaget naboer over at forretninger og næringsliv var begynt å trekke seg ut fra områdene og at bydelen ble tappet for ressurser. Dette er aggregerte konsekvenser av private preferanser som foretas av gründere og andre forretningsfolk, som det er vanskelig å endre gjennom politiske vedtak. Men en har ikke annet valg enn å forsøke å snu trenden. En må styrke byråkrati og næringsliv samt sivile institusjoner i områder som får et gjengproblem. En må bygge broer inn i lokalsamfunnet og styrke de institusjonene som er. Et bredt forebyggende ungdomsarbeid blir særdeles viktig sammen med tiltak for å motarbeide tilbaketrekning. Tilbaketrekning vil være den mest naturlige innskytelse for de fleste, også for myndighetene, når det blir uro og problemer, men den vil kunne fungere destruktivt. En forebyggende strategi på makro plan må være å styrke statens makt i utsatte områder, og å forankre makten og institusjonene i lokalbefolkningen slik at også de blir ansvarliggjort.

Det er også nødvendig å være klar over at de kriminogene krefter kan være usynlige og operere i det skjulte, slik vi har beskrevet dem i den første fase. Det har vært ungdomsklubber som har blitt forsøkt overtatt av kriminelle gjenger. Det er ungdomsinstitusjoner hvor ungdom driver med kriminell aktivitet i en type undergrundsstruktur (Andreassen 2003). Det betyr at en må styrke de antikriminogene kreftene i ungdomsklubbene, og være årvåkne for at kriminogene krefter kan snike seg inn.

I Norge er det satset mye på samarbeid mellom de enkelte kommunale innstanser som politi og sosialetat for å styrkeungdomsarbeidet og forebygge kriminalitet. Det er en SLT modell som er hentet fra Danmark. Det betyr at gode ideer flyter mellom de skandinaviske land. Imidlertid er det en utfordring. Det er positivt at systemet kan samarbeide med seg selv - at vi får et horisontalt samarbeid mellom instanser, men vi trenger også et vertikalt samarbeide som forankrer seg 
nedover i befolkningen. Når innvandrere kommer til det nye landet så konstruerer de organisasjoner og institusjoner som kan være basert på føydale strukturer altså slektskapsorganisasjoner og religiøse organisasjoner. Måten de er organisert på følger ikke nødvendigvis demokratiske prinsipper og normer, og det kan være vanskelig for et moderne samfunn å samarbeide med klan og kaste organisasjoner. En fằr altså til organisering og samarbeid innenfor en byråkratisk struktur, men samarbeidet må slo rot og involvere minoritetsbefolkningen og dette kan være langt vanskeligere. Som primær forebyggingsstrategi må vi ha en integreringsstrategi som handler om kommunikasjon, kunnskap og brobygging, og deltagelse av organisasjoner og nettverk som også er utenfor det byråkratiske system.

Migrasjon kan lede til en taushetskodeks, og denne må brytes gjennom deltagelse og kommunikasjonsarbeid som har som mål å skape trygghet. Vanlige personer i "ghettoen" kan føle seg uttrygge på grunn av mange forhold. De vil beskytte seg mot myndighetene fordi de kanskje har arrangert et tvangsekteskap, det finnes polygame ektsekap, noen har kanskje omskåret døtrene sine, andre har smuglet inn en fetter eller to, atter andre har tvilsom identitet. På grunn av slike illegale forhold som enkelte personer kan ha utført, kan en taushetskodeks etablere seg i et miljø og tausheten kan virke som en buffer mot loven og samfunnets institusjoner, noe som også kan gjøre at samarbeidet mellom beboere og myndigheter blir vanskelig. Sosiologen Micael Bjørk (2008) gjorde en studie av Gøteborgs politis arbeide og fant at politiarbeidet var særlig vanskelig i de etniske bydelene, nettopp fordi lokalmiljøet forholdt seg med taushet. De hadde mistillit til myndighetene, og holdt informasjon skjult.

\section{Politi}

I flere tilfeller har politiet blitt møtt med aggsjon og vold når de har rykket ut $\mathrm{i}$ forbindelse med konflikter mellom gjenger. Det skjedde også i august 2010 da Fyns politi i Vollmose bydel i Odense ble møtt med stein og flasker. En naturlig reaksjon i slike tilfeller vil kunne være tilbaketrekning. En annen reaksjon kan være å bevæpne seg tungt før en går inn. Vi har sett opptøyer i franske bydeler hvor politiet synes å ha opptrådt på måter som har trigget konflikter og ført til mer konfrontasjon, fordi de har bevæpnet seg tungt. Så har konfliktene eskalert med den konsekvens at både politi og statens institusjoner samt næringsliv trekker seg tilbake etter hvert.

Når det er stor aggresjon, blir politiet redd, og reagerer med å beskytte seg. $\AA$ høre at politiet si at de er redde for å gå inn i enkelte bydeler og gater, trigger også gjengenes æresfølelse, og de blir stolte. Når politiet er redd beskytter de seg bak hjelmer, skjold, patrulje biler og hunder. Det selvmotisgende er at en tung beskyttelse kan føre til at konflikten eskaleres. Politiets frykt og nervøsitet sprer 
seg, og kan skape konfrontasjon. Vi trenger derfor et politi som er så trygge at de ikke signaliserer frykt og sprer nervøsitet. Et aktivt kommunikasjonsarbeid inn i miljøet på et tidlig tidspunkt hvor politiet snakker med gjengmedlemmer og beboere og etablerer tillit og forbindelser gjør at de får oversikt og blir trygge. Når politiet har en dyp kunnskap om forholdene i lokalmiljøet blir de mindre nervøse, og kan bidra med megling og finne relevante løsninger, for å hindre eskalering. Lokalsamfunnet blir også mindre nervøse når de kjenner at personer i politiet har ro og kontroll.

En politimann på Stovner i Oslo fortalte at han hadde lært seg alle bursdagene til guttene i gjengene i området. Når han traff medlemmene på gaten kunne han si: "Hei, Ole eller hei Mohammed. I dag har du bursdag, gratulerer!" Denne hilsningen fungerte på to måter. Politimannen viste at han hadde både kontroll og kunnskap, og han viste respekt og vennlighet for guttene ved å gratulere dem. A kjenne til at nå er det Eid, eller kjenne til kallenavn til gjengmedlemmer, vite hvem som er onkel eller tante til den ene eller den andre, er slik kompetanse som en kanskje synes er unyttig, men som på lang sikt kan bryte ned en fiendtlig holdning og forhindre nervøsitet og utrygghet.

Gjenger har en fiendtlig holdning til miljøene rundt. De hater andre gjenger, og de hater samfunnet og politiet. Men på en skala fra 1 til 10 kan hatet ligge på nivå 3 eller $4, \mathrm{og}$ ikke på nivå $8,9,10$. Det blir lettere å handskes med et miljø når hatet ovenfor samfunnet ligger på et lavere nivå. Kunnskap og interaksjon vil ikke nødvendigvis fjerne hatet og antagonismen, men vil redusere det til et lavere nivå, og muliggjøre kommunikasjon og løsninger.

Gjengene har en stor tiltekning fordi gjengmedlemmer har en glans. De er tøffe og mange smågutter begynner å drømme gangsterdrømmer tidlig. En exit strategi som får medlemmer ut av gjengen, vil virke forebyggende. En må fjerne glansen av gjengen, og det norske politiet i Oslo utsatte B gjengen for en "shaming" strategi ved prosjektet Nemesis (Lien 2008). Prosjektet var slik at politiet fulgte pengestrømmene og dermed kunne de avdekke at flere familiemedlemmer hadde ulike roller og at kvinnene levde og konsumerte verdier som guttene hentet inn gjennom illegal aktivitet. Mor og far ble arrestert. Det påførte familien stor skam i det pakistanske miljøet spesielt, og viste at gjengmedlemmer ikke kunne ivareta sine forpliktelser overfor foreldrene på en ordentlig måte. De tapte ære på bakgrunn av denne manglende evne til å beskytte mor og far. Glansen forsvant og gjengmedlemmene gråt. Grunnen til at denne strategien kunne gjennomføres var at politiet hadde kunnskap om økonomi, konsum, relasjoner og kulturkompetanse.

Det er alltid sideeffekter av strategier som det kan være vanskelig å forutse. Det viktigste er at det press som utøves mot gjengene følges opp med tilbud om 
exit, ellers kan gjengproblematikken styrkes gjennom det press som settes på, for en konflikt med politiet kan stryke samholdet i gjengen. Politiet må både utsette gjengene for press, arrestere dem, men samtidig hjelpe til med finne veier ut av gjengen, dempe konflikter og megle mellom gruppene, ellers kan presset bli kontraproduktivt.

Avisene skriver gjerne om gjengmedlemmene og de intervjues på tv og radio hvor deres brutalitet omtales og beskrives. Dette øker gjengens ære, som vil være farlig, fordi det gir dem makt. Men livet i gjeng har en helt annen side som må synliggjøres mer. Livet i gjeng er et liv med store psykiske belastninger og smerter. En måte å forebygge rekruttering til gjengene på er nettopp å sette fokus og spre kunnskap om disse belastningen, den psykiske og fysiske smerte. Et gjengmedlem gjorde en opptelling over hvor mange av hans venner som var drept de sist fem årene. Han kom med et tall på ti venner han hadde mistet ved drap, og ti andre som hadde overlevd drapsforsøk. Livet i gjengen har en bakside som består av psykisk og fysiske smerte, kamerater som blir skutt og drept, samt en hel rekke andre personlige kostnader som slår ut i skjelvinger, søvnproblemer, mareritt, redsel, traumatisk stresslidelse og fremtidspessimisme. Det aller viktigste forebyggende tiltak å gjøre fremover er nettopp å fortelle ungdom på et tidlig tidspunkt om den kolossale omkostningen et liv i gjengen medfører, og å tilby psykologisk behandling til de som trenger det. Det finnes ingen lykkelige gjengmedlemmer. De er ulykkelige, deprimert, føler seg fanget av skjebnen og redde for sitt liv.

\section{Litteratur}

Andreassen, Tore (2003). Behandling av ungdom i institusjoner. Hva sier forskningen? Kommuneforlaget

Black-Michaud J. (1975). Cohesive Force: Feud in the Mediterranean and the Middle East Basil Blackwell, Oxford

Bjørk, M. (2008). 'Wolves and sheepdogs: on migration, ethnic relations and gang-police interaction in Sweeden'. van Gemert F, D. Peterson, D. \& I. L. Lien. (Red). (2008): Street Gangs, Migration and Ethnicity. Devon, UK: Willan Publishing.

Caspi A., Moffitt, T. E., Silva, P.A, Stouthamer-Loeber, M., Lrieger, R F. \& Schmutte, P.S (1994). 'Are some people crime-prone? Replications of the personality-crime relationship across countries, genders, race, and methods'. Criminology, 32, 163-95

Decker S.H and Weerman F.M (2005). European Street gangs and Troublesome Youth Groups. Lanham MD: Alta Mira Press 
Durkheim, E . (1979). Suicide: A study in Sociology. London: Routledge and Kegan Paul

Farrington, D.P., Gallagher, B., Morley, L.; St. Ledger, R. J., \& West, D.J. (1988). 'Are there any successful men from criminogenic backgrounds?' Psychiatry, 51, 116-30.

Farrington. D.P., Gundry G., \& West D.J (1975) 'The familial transmission of criminality'. Medicine, Science and the Law, 15, 177-86

Feixa, C., Canelles, M., Porzio L., Recio, C., og Luca Gilberti (2008). Latin Kings in Barcelona. van Gemert F, D., Peterson, D. \& I. L. Lien. (Red). (2008): Street Gangs, Migration and Ethnicity. Devon, UK: Willan Publishing.

Grønhaug, Reidar, 1979 [1975]. 'Nordmenn og innvandrere. Om etnisitet og klasse som to ulike forutsetninger for sosial deltakelse'. I Reidar Grønhaug, red. Migrasjon, utvikling og minoriteter. Oslo: Universitetsforlaget: 125-145.

Hagedorn, J.M. (2001). 'Gangs, Neighborhoods, and Public Policy' In Miller, J., Maxson, C.L., Klein, M.W (red) (2001). The Modern Gang Reader. Los Angeles: Roxbury Publishing Company

Klein, Malcolm (1995). The American Street Gang: Its nature, Prevalence and Control. New York/Oxford: Oxford University Press.

Klein, M.K., Kerner, H.J., Maxson C.L og Elmar G.M. Weitekamp (2001). The Eurogang Paradox. Dodrecht: Kluwer Academic Publishers.

Lien, I.L. (2005a). 'The role of crime acts in constituting the gang's mentality.' In Scott Decker and Frank Weerman (2005). European Street Gangs and Troublesome Youth Groups. Findings from the Eurogang Research Program Alta MiraPublisher.

Lien, I.L. (2005b). "Criminal gangs and their connections. Metaphors, definitions and structures". In Scott Decker and Frank Weerman (2005): European Street Gangs and Troublesome Youth Groups. Findings from the Eurogang Research Program. Alta Mira Publisher.

Lien, I.L (2004). Ugripelig Ung. Kriminalitetsforebygging og gjengbekjempelse $i$ innvandringsmiljøene. Oslo: Norsk institutt for by- og regionsforskning. NIBR-rapport 2004:13

Maughan, B., \& Lindelow M. (1997). Secular change in psychosocial risks: The case of teenage motherhood. Psychological Medicine, 27, $1129-44$

Maughan , B., Pickles, A., Hagell, A., Rutter, M, \& Yule, W. (1996). Reading problems and antisocial behaviour: Developmental Trends in comorbidity. Journal of Child Psychology and Psychiatry, 37, 405 - 18

Nisbett R and Cohen d.( 1996). The culture of honour. The psychology of violence in the South, Boulder

Offord, D. R. (1982). 'Family backgrounds of male and female delinquents'. In J. 
Gunn \& \& Farrington D.P. (eds): Abnormal offenders: Delinquency and the criminal justice system, Chichester: Wiley

Putnam R. D. (2007). 'E pluribus unum: diversity and community in the twentyfirst century. The Johan Skytte Prize Lecture", Scandinavian Political Studies, $30(2), 137-74$

Rutter, M., Giller H., \& Ann Hagel (2004). Antisocial Behavior by Young People. Cambridge: Cambridge University Press

Rutter M., \% Giller, H., (1983). Juvenile Delinquency: Trends Trends and perspectives. Harmondsworth: Penguin

Sandberg, S. \& Pedersen W. (2006). Gatekapital. Oslo: Universitetsforlaget

Thrasher, F.M. (1927). The gang: A study of 1,1313 Gangs in Chicago. Chicago University of chicago Press.

Van Gemert F, D. Peterson, D. \& I. L. Lien. (Red). (2008). Street Gangs, Migration and Ethnicity. Devon, UK: Willan Publishing

Waters, T. (1999). Crime and immigrant Youth. London: Sage Publication.

\section{Notes:}

1 I følge Eurogang's definsjon er en gjeng en gateorientert ungdomsgruppe som har eksistert over noen måneder eller mer, hvis identitet er basert på at de driver med illegale aktiviteter sammen (Decker og Weerman 2005). At gruppen er gateorientert betyr at den oppholder seg mer utendørs enn innendørs, i biler og parker etc. Ung betyr at den er i tenårene eller i tyveårene. Illegal aktiviteter betyr kriminell eller plagsom atferd. Identitet refererer seg til gruppen og ikke til individets selvbilde.

Adress:

Nasjonalt kunnskapssenter om vold og traumatisk stress

Kirkeveien 166, bygning 48

0407 Oslo

e-post: i.1.ien@nkvts.unirand.no 